Investigation of influence of moon tides on the electromagnetic field of the atmosphere boundary layer with the method of eigen vectors

*L.V. Grunskaya, D.V. Rubay, V.V. Isakevich, D.V. Isakevich (Valdimir State University) SUMMARY

In 2012 there was continued to operate the multichannel synchronic monitoring system of electrical and geomagnetic fields at the spaced apart stations: VSU physical experimental proving ground; the station of the Institute of Solar and Terrestrial Physics of Russian Academy of Science (RAS) at Lake Baikal; the station of the Institute of volcanology and seismology of RAS in Paratunka; the station in Obninsk on the base of the scientific and production society "Typhoon". There has been developed a programme analytical system for investigating the structure of signals in spectral and time ranges caused by geophysical processes. Using the method of spectral analysis of eigen vectors in many years' time series of the electrical field vertical component slowed its efficiency for exposing periodical components with a relative energetical contribution up to 10-4. The work is carried out with supporting of RFFI № 11-05-97518, FPP №14.B37.21.0668., FPP №5.2971.2011.

\title{
Исследования воздействия лунных приливов на электромагнитное поле пограничного слоя атмосферы с помощью метода собственных векторов
}

*Л.В. Грунская, Д.В. Рубай, В.В. Исакевич, Д.В. Исакевич (Владимирский государственный университет)

\section{PEЗЮME}

В 2012 году обеспечено действие системы многоканального синхронного мониторинга электрического и геомагнитного полей на разнесенных в пространстве станциях: физический экспериментальный полигон ВлГУ; станция на оз. Байкал Института солнечно-земной физики СО РАН; станция в п. Паратунка (Камчатка), Институт вулканологии и сейсмологии ДВО РАН; станция в г. Обнинск на базе научно-производственного объединения «Тайфун». Разработан программно-аналитический комплекс для исследования структуры сигналов в спектральной и временной областях, вызванных геофизическими процессами. Использование метода спектрального анализа собственных векторов в многолетних временных рядах вертикальной составляющей электрического поля показало его эффективность для выявления периодических составляющих с относительным энергетическим вкладом вплоть до 10-4. Работа осуществляется при поддержке гранта РФФИ №11-05-97518, ФЦП 14.B37.21.0668., Государственного Задания 5.2971.2011. 
В 2012 году обеспечено действие системы многоканального синхронного мониторинга электрического и геомагнитного полей на разнесенных в пространстве станциях: физический экспериментальный полигон ВлГУ; станция на оз. Байкал Института солнечно-земной физики СО РАН; станция в п. Паратунка (Камчатка), Институт вулканологии и сейсмологии ДВО РАН; станция в г. Обнинск на базе научно - производственного объединения «Тайфун».

Разработан программно - аналитический комплекс для исследования структуры сигналов в спектральной и временной областях, вызванных геофизическими процессами. Использование метода спектрального анализа собственных векторов в многолетних временных рядах вертикальной составляющей электрического поля показало его эффективность для выявления периодических составляющих с относительным энергетическим вкладом вплоть до $10^{-4}$.

Работа осуществляется при поддержке гранта РФФИ №11-05-97518, ФЦП 14.В37.21.0668., Государственного Задания 5.2971.2011.

In 2012 there was continued to operate the multichannel synchronic monitoring system of electrical and geomagnetic fields at the spaced apart stations: VSU physical experimental proving ground; the station of the Institute of Solar and Terrestrial Physics of Russian Academy of Science (RAS) at Lake Baikal; the station of the Institute of volcanology and seismology of RAS in Paratunka; the station in Obninsk on the base of the scientific and production society "Typhoon"

There has been developed a programme analytical system for investigating the structure of signals in spectral and time ranges caused by geophysical processes. Using the method of spectral analysis of eigen vectors in many years' time series of the electrical field vertical component slowed its efficiency for exposing periodical components with a relative energetical contribution up to $10^{-4}$.

The work is carried out with supporting of RFFI № 11-05-97518, FPP № 14.B37.21.0668., FPP №5.2971.2011 